\title{
Fast Corner Detection in Augmented Reality Learning Management of the Corpse
}

\author{
Undang Syaripudin \\ Department of ICT, Asia E-University, Kuala Lumpur, Malaysia \\ Department of Informatics, UIN Sunan Gunung Djati Bandung, Indonesia \\ E-mail: undang_if@uinsgd.ac.id
}

Diena Rauda Ramdania, Wine Widiawaty, Wildan Budiawan Zulfikar and Dian Sa'adillah Maylawati

Department of Informatics, UIN Sunan Gunung Djati Bandung, Indonesia

E-mail: diena.rauda@uinsgd.ac.id,widiawatywine@gmail.com,wildan.b@uinsgd.ac.id,diansm@uinsgd.ac.id

\section{Student paper}

Keywords: augmented reality, corpse management, FAST corner detection

Received: June 4, 2021

\begin{abstract}
50 out of 170 senior high school students do not understand the material of the corpse management practicum. This study aims to make it easier for students to understand better and remember caring for corpses in the classroom. A learning application for managing bodies made using Augmented Reality $(A R)$ technology. The algorithm used is FAST Corner Detection. This algorithm's sequence is: resizing the image, changing the image to grayscale, smoothing the gray color (histogram), and determining the threshold as a determining point for the point marker. This application contains material on the procedures for bathing, praying, and burying the body. The FAST Corner Detection algorithm's performance takes 0.41 seconds to detect an object and can be done at a distance of 1 meter. The application also meets $82.8 \%$ of the user side's usability level, which indicates that this application is beneficial for learning. Interface testing gets a final score of $90.7 \%$. This result suggests that the application is in outstanding criteria.
\end{abstract}

Povzetek: Predstavljena je androidna aplikacija za obravnavo trupel s pomočjo obogatene realnosti.

\section{Introduction}

The material for managing the corpse is one of the competencies that high school students must master. However, based on a survey conducted on 170 vocational school students, only 50 of them already understand the practice of caring for corpses. Most students fail because they do not know how to cover their bodies following Islamic religious practices. Several previous studies have captured the urgency of students' understanding of the handling of bodies. For example, by making Android applications[1]-[3], video assisted[4], mobile learning[5], et cetera. However, no application visualizes explicitly it in the form of Augmented Reality.

This study aims to create Augmented Reality-based learning media for learning corpse care. The FAST Corner Detection algorithm is applied to augmented reality, and then its performance is tested. FAST corner detection has been tested in several previous studies with various purposes. For example, learning tajweed [6], knowing the authenticity of batik cloth [7], learning about computer hardware introduction [8], introducing animals for children [9]-[11], zoos [12], introducing books [13], building history [14], interior design [15], learning the Japanese language for children [16], even songbooks to increase music awareness [17]. Various studies that have applied FAST Corner prove that this algorithm has good performance.

In order to prove the performance of the algorithm, the application will be tested to determine the reusability of the Augmented Reality system for body management by alpha testing (black box system testing) and beta (direct user testing).

\section{Corpse management}

The management of the corpse means what Muslims do to other Muslims who die, which includes bathing, praying, forgiving, and washing them.

Some things to do with the person who died:

\section{Bathing the body}

Requirements for washing the body:

a. The body of a Muslim,

b. There is a body even a little,

c. The body was not martyred.

\section{Forgive the body}

The law of forgiving the corpse must be done (fardhu kifayah) and do it as well as possible according to the argument: "If you forgive the corpses of your brothers, 
caravan as best you can." (H.R. Muslim from Jabir Abdullah r.a.)

The shroud itself is obtained from the treasure that was left behind. If no property is left behind, then the cover is the living duty and if the living does not have property, then take it from baitul-mal.

The shroud is at least a layer of cloth covering the body. Three layers of material are better for men and five layers for women. One of the fabrics is the bath cloth. How to forgive the body[18]:

a. Spread the shroud strand by strand by sprinkling camphor on each layer

b. The corpse was placed on it

c. The hands are folded over the chest, and the right hand is placed on the left hand

\section{Dress the body}

Following the hadits: "From Salamah bin Al-Akwa, "At one point, we were sitting near the Prophet SAW. He said to us, "Pray your friends" (H.R.Bukhari).

Requirements for burying the body [19]:

a. Close the genitals, body, and clothing, facing the Qibla.

b. Carry out after the body is bathed and put on a shroud.

c. The body is placed next to the Qibla of the person who is praying.

Procedure for burying the body [18]:

a. The body is placed in front of the congregation. If the body is a boy, the priest stands near the head of the body. If the body is a woman, the priest stands near the stomach.

b. The Imam stands at the very front, followed by the congregation behind him.

c. Start with the intention followed by four Takbir. General reading with the intention of: "Usholli a'la haada mayyiti arba'a takbiratin fardholfayati makmuman lillahi ta'ala"

Meaning: "I intend to pray on this corpse four takbir fardhu kifayah as a congregation because Allah ta'ala"

d. Takbiratul ihram who was the first to read the letter Al-Fatihah

$e$. The second takbir read shalawat on Prophet Muhammad SAW: "Allohumma sholli a'la muhammadin wa a'la aaaaali muhammadin"

f. The third Takbir read the funeral prayer: "Allohummaghfirlahu warhamhu waa'fihi wa'fu anhu"

Meaning: "O Allah, forgive him, have mercy on him, prosper him, forgive his mistakes"

g. The fourth takbir continues by reading a prayer: "Allohumma la tahrimna ajrahu wala taftinna ba'dahu waghfirlana walahu"

Meaning: O Allah, do not make us a barrier to getting his reward and not giving us slander after he died and forgiving him and us. " (H.R. Hakim)

h. Read greetings

\section{Burying the body}

Explanation of burying the body[20]:

a. The law of burying the body is fardu kifayah. There is no smell of the corpse in the grave, and wild animals do not dismantle it.

b. It is advisable to use a lahad hole (placing a corpse in a burial niche covered by planks, bamboo, etcetera.) if the soil is hard. If the ground is not hard, it is better to make a center hole (a small hole in the middle of the grave that contains the corpse)[19].

c. It is better to bury during the day, allowing for the night if the situation is urgent. When laying down the body, read[18] mustmusta:

d. Bismillahi wa'ala millati rasulillahi

e. Meaning: "In the name of Allah and the name of the religion of the Prophet."

f. Before being buried, the heir or family should be the guarantor and settle all debts, if any. Assets are taken from purchases left behind or donations from their families.

\section{Natural feature tracking and FAST algorithm}

Augmented Reality can run on mobile platforms. The limitations in the cellphone itself lead to reconsidering the development of this AR. Natural Feature Tracking itself is helpful as an algorithm used to detect points or angles to bring up 3D-shaped objects to the real world. One of the Natural Feature Tracking methods used is the FAST (Features from Accelerated Segment Test) algorithm. This method was developed by Edward Rosten, Reid Porter, and Tom Drummond. The purpose of this FAST is to accelerate the computation time in real-time with the detection of image points or angles[21].

This FAST method defines how well the image is detected and tracked using Vuforia as the image storage data. The detection is also based on a 0-5 rating. If the rating is 0 , the image does not exist, while 5 indicates that the idea is easier to trace[20]. FAST detects by looking for points or angles on an object and used them interchangeably. The detection starts from the edge (edge), and then edge analysis is carried out to detect the Corner quickly.

The process that occurs[20]:

1. Resize

The image is uploaded to Vuforia so that it automatically reduces the image to $320 \times 320$ pixels (Figure 1).

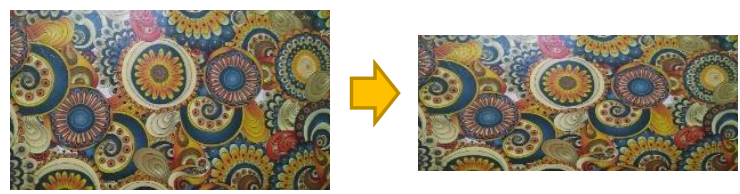

Figure 1: Resize process. 


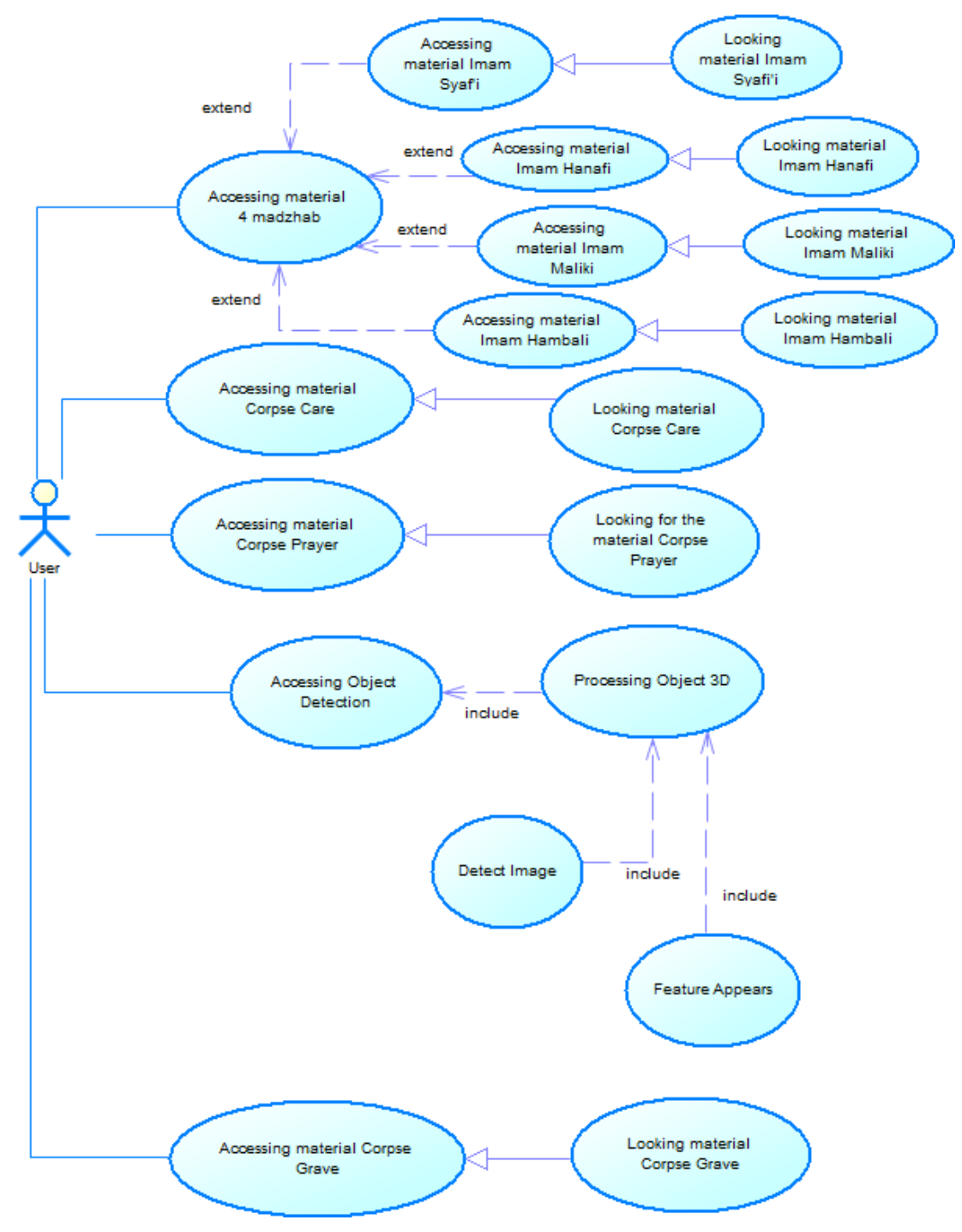

Figure 5: Use case Diagram.

2. Grayscale

The image is converted to monochrome with an intensity of 0 for black. Two hundred fifty-five for white, and gray for the value range $0-255$. With the formula new pixel $=($ Red + Green + Blue $) / 3$ (Figure 2).

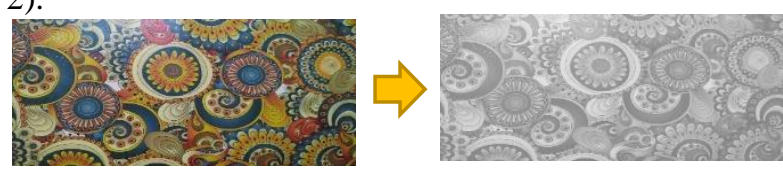

Figure 2: Grayscale process.

3. Histogram

This process is for smoothing the degree of gray in the image (Figure 3).
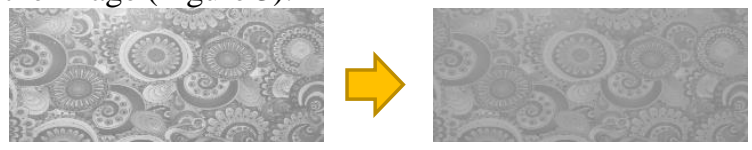

Figure 3: Histogram process.

4. Threshold
This process is included in the Vuforia library, which is done before the object is converted to point markers. The result of this process is the marker corner points which are finally converted into a threshold form.

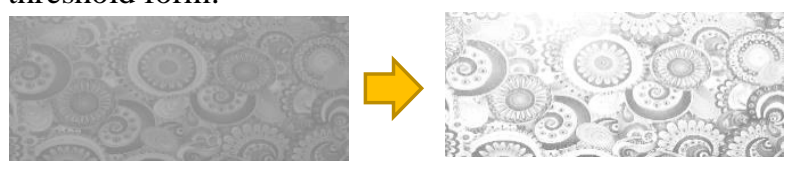

Figure 4: Threshold process.

5. Determination of the corner points

Finally, the determination of this point uses the FAST algorithm. The process results from the threshold are processed to determine the location of the issues. The coordinates are unique to each Augmented Reality object image.

\section{Result and discussion}

Use Case Diagrams are diagrams that model business processes that will describe the interactions between internal, external, and user systems[22]. The Sequence 


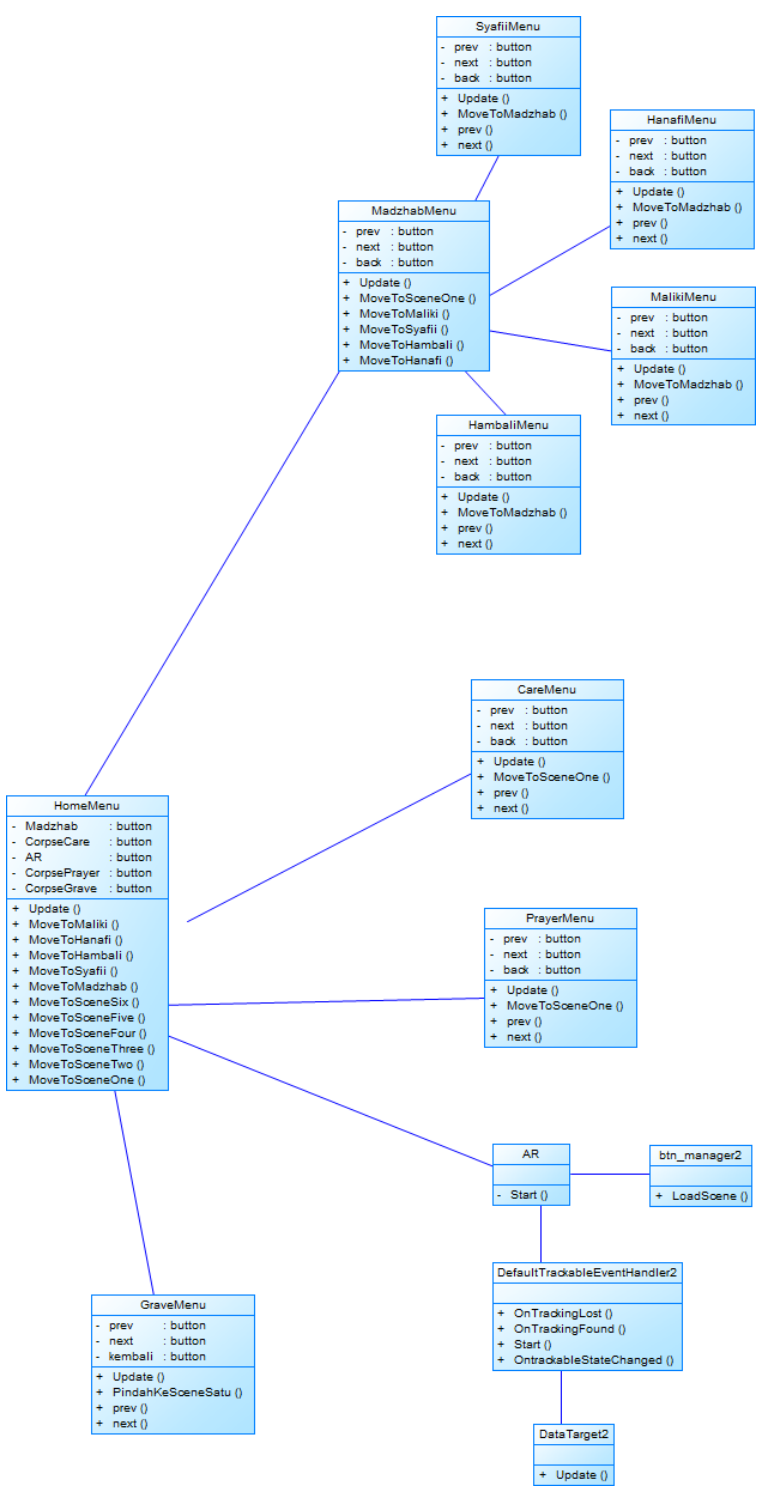

Figure 6: Sequence Diagram.

Diagram is an interaction between several objects in a certain time sequence. This process describes a series of messages between objects and their interactions at a certain point.

Use case diagrams and Sequence Diagrams built on the design created shows in Figures 5 and 6 below.

The application interface consists of the following parts:

1. Home User Interface

This menu is the initial part that will appear when the application is opened. In this User Interface, there are menus: 4 schools of thought, the body management menu, the corpse prayer menu, AR forgives, the burial menu (Figure 7).

2. User Interface 4 Mazhab

This menu is part of the first menu that will appear when the user clicks the comparison of 4 Mazhab of thought. This section will compare the 4 Mazhab regarding the management of the corpse (Figure 8).

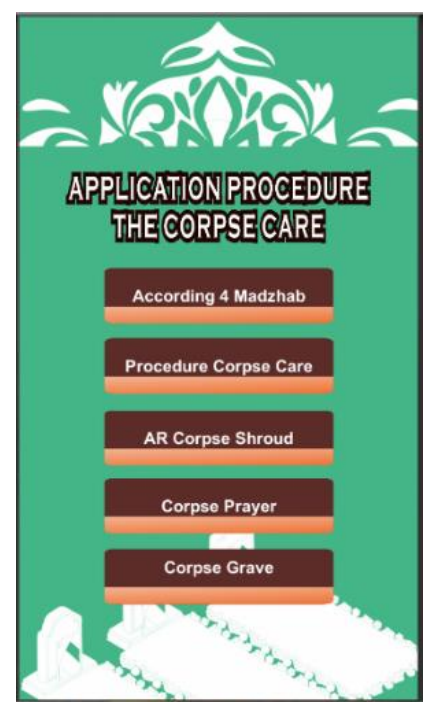

Figure 7: Home User Interface.

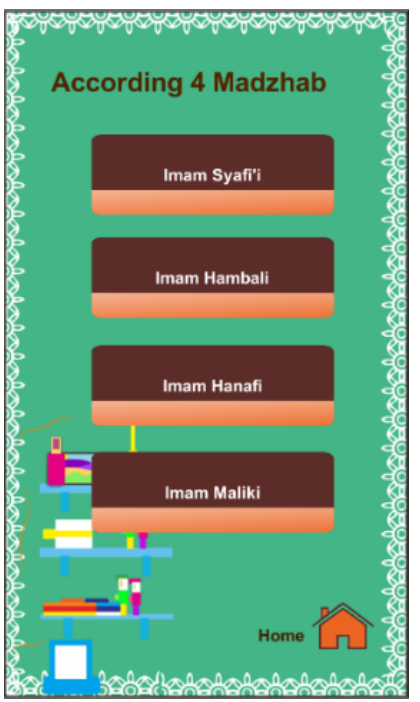

Figure 8: User Interface 4 Mazhab.

This menu is part of the second menu, namely the body's management when clicked. This section will present the procedures for taking care of the corpse (Figure 9).

4. User Interface for the Prayer of the Body

This menu is part of the third menu, namely the funeral prayer when clicked. In this section, we will present the procedures for funeral prayers (Figure 10).

5. User Interface Burying the Body

This menu is part of the fourth menu. Bury the body that will come out when clicked. This section will present the procedures for burying the body (Figure 11).

6. AR User Interface

This menu is the AR part of the application. The user points the camera at the target image, and then a 3D object will appear (Figure 12).

3. User Interface for the management of the corpse 


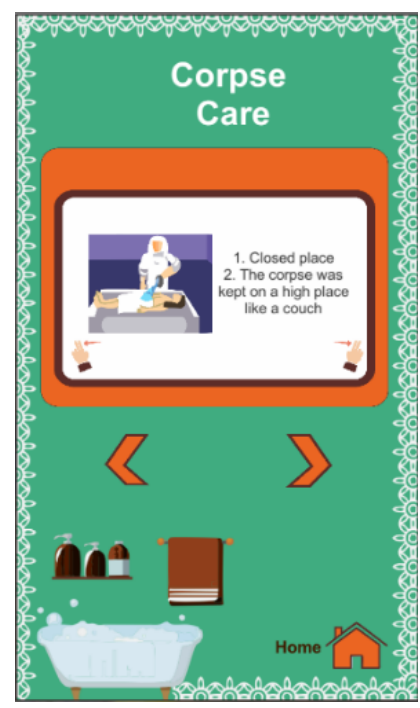

Figure 9: User Interface for the management of the corpse.

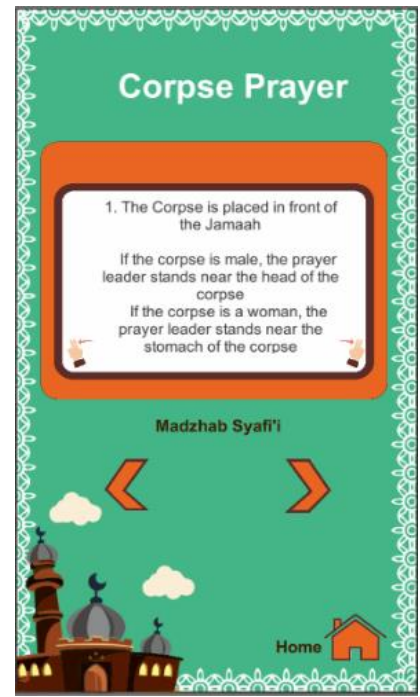

Figure 10: User Interface for Corpse Prayers.

\subsection{The alpha testing}

Alpha testing is carried out by users who are in a developer environment[23]. Testing was carried out using the Blackbox method, with the results presented in Table 1 below.

\subsection{The betha testing}

This test is carried out directly to the end-user to evaluate data from its usability, function, compatibility, and reliability testing[24]. The user response questionnaire to this application consists of 5 questions, and the answer uses a scale of 1 to 5 .

Following are the questionnaire questions:

1. Is funeral management a practical application for Muslims?

2. Is the application using ARsmartphone beneficial for Muslims?

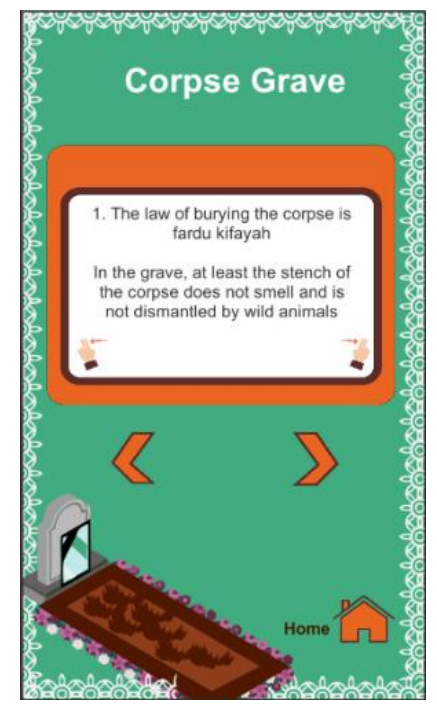

Figure 11: User Interface Burying the Body.

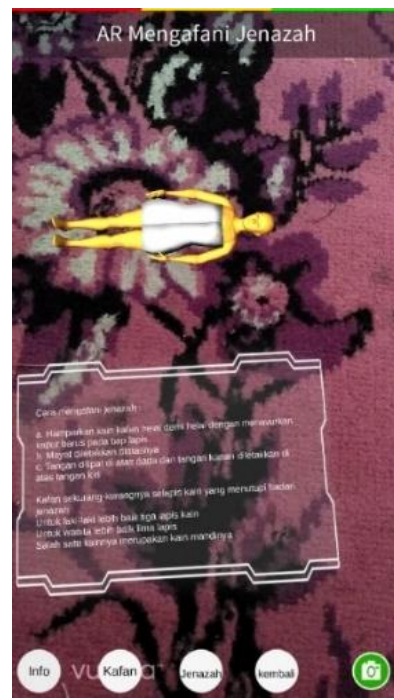

Figure 12: AR User Interface.

Table 1: Blackbox testing result.

\begin{tabular}{|c|l|l|l|}
\hline Code & $\begin{array}{l}\text { Test } \\
\text { Component }\end{array}$ & Item Test & Result \\
\hline 01 & Home & $\begin{array}{l}\text { Displaying all } \\
\text { menu buttons }\end{array}$ & Success \\
\hline 02 & $\begin{array}{l}\text { Menu 4 } \\
\text { Mazhab }\end{array}$ & $\begin{array}{l}\text { Displaying } \\
\text { material 4 Mazhab }\end{array}$ & Success \\
\hline 03 & $\begin{array}{l}\text { Body } \\
\text { Management } \\
\text { Menu }\end{array}$ & $\begin{array}{l}\text { Displaying body } \\
\text { handling material }\end{array}$ & Success \\
\hline 04 & $\begin{array}{l}\text { The Prayer } \\
\text { Menu }\end{array}$ & $\begin{array}{l}\text { Displaying corpse } \\
\text { prayer materials }\end{array}$ & Success \\
\hline 05 & $\begin{array}{l}\text { AR Menu } \\
\text { Putting on a }\end{array}$ & $\begin{array}{l}\text { Displaying 3D } \\
\text { objects }\end{array}$ & Success \\
\hline 06 & Burial Menu & $\begin{array}{l}\text { Displaying } \\
\text { material burying } \\
\text { corpses }\end{array}$ & Success \\
\hline
\end{tabular}


Table 2: Betha test Result.

\begin{tabular}{|c|c|c|c|}
\hline Statement & Value & Score & $\begin{array}{l}\text { Total } \\
\text { Score }\end{array}$ \\
\hline \multicolumn{4}{|c|}{ Question 1} \\
\hline $\begin{array}{l}\text { Strongly } \\
\text { Agree }\end{array}$ & 5 & 18 & 90 \\
\hline Agree & 4 & 22 & 88 \\
\hline Less Agree & 3 & 3 & 9 \\
\hline Disagree & 2 & 0 & 0 \\
\hline $\begin{array}{l}\text { Strongly } \\
\text { Disagree }\end{array}$ & 1 & 1 & 1 \\
\hline \multicolumn{4}{|c|}{ Total: $85.5 \%$} \\
\hline \multicolumn{4}{|c|}{ Question 2} \\
\hline $\begin{array}{l}\text { Strongly } \\
\text { Agree }\end{array}$ & 5 & 12 & 60 \\
\hline Agree & 4 & 30 & 120 \\
\hline Less Agree & 3 & 1 & 3 \\
\hline Disagree & 2 & 1 & 2 \\
\hline $\begin{array}{l}\text { Strongly } \\
\text { Disagree }\end{array}$ & 1 & 0 & 0 \\
\hline \multicolumn{4}{|c|}{ Total: $84.1 \%$} \\
\hline \multicolumn{4}{|c|}{ Question 3} \\
\hline $\begin{array}{l}\text { Strongly } \\
\text { Agree }\end{array}$ & 5 & 13 & 65 \\
\hline Agree & 4 & 25 & 100 \\
\hline Less Agree & 3 & 4 & 12 \\
\hline Disagree & 2 & 2 & 4 \\
\hline $\begin{array}{l}\text { Strongly } \\
\text { Disagree }\end{array}$ & 1 & 0 & 0 \\
\hline \multicolumn{4}{|c|}{ Total: $82.3 \%$} \\
\hline \multicolumn{4}{|c|}{ Question 4} \\
\hline $\begin{array}{l}\text { Strongly } \\
\text { Agree }\end{array}$ & 5 & 7 & 35 \\
\hline Agree & 4 & 31 & 124 \\
\hline Less Agree & 3 & 6 & 18 \\
\hline Disagree & 2 & 0 & 0 \\
\hline $\begin{array}{l}\text { Strongly } \\
\text { Disagree }\end{array}$ & 1 & 0 & 0 \\
\hline \multicolumn{4}{|c|}{ Total: $80.4 \%$} \\
\hline \multicolumn{4}{|c|}{ Question 5} \\
\hline $\begin{array}{l}\text { Strongly } \\
\text { Agree }\end{array}$ & 5 & 11 & 55 \\
\hline Agree & 4 & 29 & 116 \\
\hline Less Agree & 3 & 2 & 6 \\
\hline Disagree & 2 & 1 & 2 \\
\hline $\begin{array}{l}\text { Strongly } \\
\text { Disagree }\end{array}$ & 1 & 1 & 1 \\
\hline
\end{tabular}

3. Can this application using ARsmartphone help understand Islamic Education in class or Muslims in everyday life handling corpses?

4. Is the AR smartphone application good enough in the formation of $3 \mathrm{D}$ objects from handling the corpse?

5. Is the operation of the corpse management application easy to use?

The User Interface testing questionnaire conducted by three people according to Jacob Nielsen's theory [25]
Table 3: Usability test Result.

\begin{tabular}{|c|c|c|c|}
\hline Statement & Value & Score & $\begin{array}{l}\text { Total } \\
\text { Score }\end{array}$ \\
\hline \multicolumn{4}{|c|}{ Question 1} \\
\hline Very good & 5 & 2 & 10 \\
\hline Good & 4 & 1 & 4 \\
\hline Enough & 3 & 0 & 0 \\
\hline Bad & 2 & 0 & 0 \\
\hline Very bad & 1 & 0 & 0 \\
\hline \multicolumn{4}{|c|}{ Total: $93.3 \%$} \\
\hline \multicolumn{4}{|c|}{ Question 2} \\
\hline Very good & 5 & 2 & 10 \\
\hline Good & 4 & 1 & 4 \\
\hline Enough & 3 & 0 & 0 \\
\hline Bad & 2 & 0 & 0 \\
\hline Very bad & 1 & 0 & 0 \\
\hline \multicolumn{4}{|c|}{ Total: $93.3 \%$} \\
\hline \multicolumn{4}{|c|}{ Question 3} \\
\hline Very good & 5 & 1 & 5 \\
\hline Good & 4 & 2 & 8 \\
\hline Enough & 3 & 0 & 0 \\
\hline $\mathrm{Bad}$ & 2 & 0 & 0 \\
\hline Very bad & 1 & 0 & 0 \\
\hline \multicolumn{4}{|c|}{ Total: $86.7 \%$} \\
\hline \multicolumn{4}{|c|}{ Question 4} \\
\hline Very good & 5 & 1 & 5 \\
\hline Good & 4 & 2 & 8 \\
\hline Enough & 3 & 0 & 0 \\
\hline $\mathrm{Bad}$ & 2 & 0 & 0 \\
\hline Very bad & 1 & 0 & 0 \\
\hline \multicolumn{4}{|c|}{ Total: $86.7 \%$} \\
\hline \multicolumn{4}{|c|}{ Question 5} \\
\hline Very good & 5 & 2 & 10 \\
\hline Good & 4 & 1 & 4 \\
\hline Enough & 3 & 0 & 0 \\
\hline Bad & 2 & 0 & 0 \\
\hline Very bad & 1 & 0 & 0 \\
\hline \multicolumn{4}{|c|}{ Total: $93.3 \%$} \\
\hline
\end{tabular}

consists of 5 questions, and the answers use a scale of 1 to 5 .

Following are the questionnaire questions:

1. Can the system provide information that the image detection was successful or failed in the funeral application under the usability "Visibility of system status"?

2. Does the icon in the count processing application match the "Match between system and the real world" usability?

3. Are the excellent color contrast, appropriate position, and harmony made in the corpse management application per the usability "Consistency and standards"?

4. Does the system design made in the corpse management application focus on following the usability of "Aesthetic and minimalist design"?

5. Are the red, yellow, green indicators on the top of the bar in the AR display created in the corpse 
management application to provide bug error information in detecting images by usability "Error prevention"?

Based on the alpha test results, it can be concluded that the application for managing the corpse was built as expected, namely in terms of the emergence of material displacement and the maximum in the form of a 3D object. The target image is according to the camera's focus on the Android mobile which can detect up to 0.41 seconds in detecting objects with a distance of up to 1 meter. These results are obtained by calculating the appearance of the 3D model using a stopwatch.

Beta testing on the body management application built according to 44 user responses can be concluded that this application is easy to use and very helpful for students in learning Islamic Education. This is obtained from the percentage of user responses through a questionnaire that reaches $82.8 \%$. The rate indicates that the application is categorized as strongly agreeing that the application for managing bodies is presented in an AR Smartphone. According to Jacob Nielsen's theory, testing the application User Interface according to 3 testers reached $90.7 \%$. This application was categorized as very good according to the principles of Jacob Nielsen's User Interface theory.

\section{Conclusion}

An AR application has been built as a learning medium. Since this application is presented in a mobile Android form, it can be used to learn about the Management of Bodies in any case. It is also simple to bring around because it is presented in a mobile android form. In this application, the process carried out by the system is the material for bathing, shrouding, praying, and burying the body. The material is presented in Augmented Reality technology with the FAST Corner Detection algorithm and accompanied by dzikir backgrounds for the shroud. The FAST Corner Detection algorithm performs the process starting from detecting the target image, which does not take long. The average detection speed reaches 0.41 seconds per object with a distance of up to 1 meter. Markerless, which is applied in this application, users do not need to use unique markers to appear as predetermined digital elements. The level of usability testing of the corpse management application system is outstanding. This test data is obtained from alpha testing data that can detect Image Target according to the camera's focus on the Android mobile, which reaches 0.41 seconds. The distance of up to 1 meter and beta testing is obtained from user response questionnaire data which comes $82.8 \%$ categorized as very helpful in PAI learning materials and everyday life in caring for corpses. The User Interface test data reached $90.7 \%$, which was classified as very good according to Jacob Nielsen's theory principles.

\section{Acknowledgement}

Authors wishing to acknowledge the Faculty of Sciencw and Technology of UIN Sunan Gunung Djati Bandung that supports and funds this research publication.

\section{References}

[1] A. Thomas Faizal, M. K. H. Wahyudin, and H. M. A. Deden Nurul, "Pengembangan Aplikasi Pengurusan Jenazah Islam Berbasis Android," J. Algoritm. Sekol. Tinggi Teknol. Garut, pp. 1-8, 2014.

[2] S. Adrianto, A. Linarta, and M. Erwin, "Aplikasi Tata Cara Pengurusan Jenazah Islam Berbasis Android," INFORMATIKA, vol. 12, no. 2, pp. 26-32, 2020.

[3] M. A. W. Prasetyo, Z. Karini, and H. Al Ayubi, "Penggunaan Smartphone Application Guna Mempelajari Cara Mengurus Jenazah Umat Muslim," INTEK J. Penelit., vol. 6, no. 2, pp. 98 105, 2019.

[4] A. Dell'Amore et al., "Human corpse model for video-assisted thoracoscopic lobectomy simulation and training," Interact. Cardiovasc. Thorac. Surg., vol. 31, no. 5, pp. 632-637, 2020.

[5] M. T. P. Aprianto, S. Ulfa, and A. Husna, "Pengembangan Multimedia Interaktif Mobile Learning Pengurusan Jenazah," J. Kaji. Teknol. Pendidik., vol. 4, no. 1, pp. 23-32, 2021.

[6] A. P. Andriyandi, W. Darmalaksana, D. S. adillah Maylawati, F. S. Irwansyah, T. Mantoro, and M. A. Ramdhani, "Augmented reality using features accelerated segment test for learning tajweed," Telkomnika (Telecommunication Comput. Electron. Control. vol. 18, no. 1, pp. 208-216, 2020, doi 10.12928/TELKOMNIKA. V18I1. 14750, 2020.

[7] D. Ramdoni, T. Sugiharto, A. Permana, and R. Nugraha, "Implementation of the FAST Fast Corner Detection Algorithm (Feature Form Accelerated Segment Test) and Augmented Reality to Determine the Authenticity of Batik Case Study (Batik Trusmi) Cirebon," Balong Int. J. Des., vol. 1, no. 1, 2019.

[8] A. Wiharto and C. Budihartanti, "Aplikasi Mobile Augmented Reality Sebagai media Pembelajaran Pengenalan Hardware Komputer Berbasis Android," PROSISKO, 2017, [Online]. Available: https://www.scribd.com/document/423068668/3871088-1-PB-1.

[9] A. Syahputra, S. Andryana, and A. Gunaryati, "Aplikasi Augmented Reality (AR) dengan Metode Marker Based sebagai Media Pengenalan Hewan Darat pada Anak Usia Dini menggunakan Algoritma Fast Corner Detection (FCD)," J. JTIK (Jurnal Teknol. Inf. dan Komunikasi), vol. 5, no. 1, pp. 4356, 2020.

[10] E. R. Nainggolan, H. H. Asymar, A. R. A. Nalendra, F. Sulaeman, and U. Radiyah, "The implementation of augmented reality as learning media in introducing animals for early childhood education," 
in 2018 6th International Conference on Cyber and IT Service Management (CITSM), 2018, pp. 1-6.

[11] B. Syihabudin, "The introduction of 3D applications Animal In Indonesia Using Augmented Reality Marker-Based Tracking Method," J. Tek. Inform. CIT Medicom, vol. 10, no. 2, pp. 14-22, 2018.

[12] F. R. Effendy, "PENGENALAN HEWAN BERBASIS AUGMENTED REALITY MENGGUNAKAN ALGORITMA FAST CORNER DETECTION PADA KEBUN BINATANG RAGUNAN." Universitas Pembangunan Nasional Veteran Jakarta, 2019.

[13] S. I. W. Putra, "Implementasi Teknologi Markerless Augmented Reality Menggunakan Metode Algoritma FAST Corner Detection Berbasis Android (Studi kasus multimedia buku interaktif kebudayaan lokal kalimantan barat )," vol. 07, No. 01, pp. 1-10, 2019.

[14] M. Fayiz, N. Hilmy, U. Darusalam, and A. Rubhasy, "Augmented Reality sebagai Media Edukasi Sejarah Bangunan Peninggalan Kesultanan Utsmaniyah menggunakan Metode Marker Based Tracking dan Algoritma Fast Corner Detection," J. JTIK (Jurnal Teknol. Inf. dan Komunikasi), vol. 4, no. 2, pp. 138 146, 2020.

[15] M. T. Samant and M. S. Vartak, "INTERIOR DESIGN USING AUGMENTED REALITY," Int. Res. J. Eng. Technol., vol. 6, no. 1, pp. 1003-1007, 2019.

[16] S. Effendi and S. M. Hardi, "Implementasi Augmented Reality Pembelajaran Bahasa Jepang pada Pengenalan Perabotan Kamar Tidur Menggunakan Huruf Hiragana Bagi Anak-Anak dengan Menggunakan Algoritma Fast Corner Detection," 2017.

[17] M. Rusiñol, J. Chazalon, and K. Diaz-Chito, "Augmented songbook: an augmented reality educational application for raising music awareness," Multimed. Tools Appl., vol. 77, no. 11, pp. 13773-13798, 2018.

[18] Mustahdi and Mustahkim, Pendidikan Agama Islam dan Budi Pekerti. Pusat Kurikulum dan Perbukuan, Balitbang, Kemendikbud., 2017.

[19] S. Rasjid, Fiqh Islam. Penerbit Sinar Baru Algensindo Bandung, 2001.

[20] I. Mulyana, M. I. Suriansyah, and J. Akbar, "Implementasi Natural Feature Tracking Pada Pengenalan Mamalia Laut Berbasis Augmented Reality," Semin. Nas. Teknol. Inf. dan Multimed., pp. 13-18, 2018, [Online]. Available:

https://ojs.amikom.ac.id/index.php/semnasteknome dia/article/view/2008/1817.

[21] B. Setiadi and E. B. Setiawan, "Aplikasi Penerjemah Tablatur Gitar Menggunakan Teknologi Augmented Reality Pada Platform Android," J. Ultim. InfoSys, vol. 7, no. 2, pp. 86-93, 2016, doi: 10.31937/si.v7i2.545.

[22] D. Irmayani, Rekayasa Perangkat Lunak, Bahasa Ind., vol. 2, no. 3. Yogyakarta: ANDI, 2019.

[23] "ALPHA TESTING." https://sis.binus.ac.id/2016/12/16/alpha-testing/ (accessed Apr. 11, 2021).

[24] "BETA TEST."

https://sis.binus.ac.id/2016/12/16/beta-test/ (accessed Apr. 11, 2021).

[25] Olehabib, "Part 1 - Menggunakan Prinsip Jacob Nielsen's Heuristic untuk Meningkatkan Usability pada User Interface."

https://medium.com/@olehabib/menggunakanprinsip-jacob-nielsens-heuristic-untuk-usability-uiux-design-yang-lebih-baik-9d583daaeeb5. 